\title{
Tailored Enzymatic Synthesis of Chitooligosaccharides with Different Deacetylation Degrees and Their Anti-Inflammatory Activity
}

\author{
P. Santos-Moriano ${ }^{1,2}{ }^{\text {, P. Kidibule }}{ }^{3}$ (D) N. Míguez ${ }^{1}$, L. Fernández-Arrojo ${ }^{1}$, A.O. Ballesteros ${ }^{1}$, \\ M. Fernández-Lobato ${ }^{3}$ (D) and F.J. Plou ${ }^{1, *(\mathbb{D})}$ \\ 1 Instituto de Catálisis y Petroleoquímica, CSIC, 28049 Madrid, Spain; \\ palomacarmen.santos@universidadeuropea.es (P.S.-M.); noa.miguez@csic.es (N.M.); \\ lucia@icp.csic.es (L.F.-A.); a.ballesteros@icp.csic.es (A.O.B.) \\ 2 Applied Biotechnology Group, Faculty of Biomedical and Health Sciences, Universidad Europea de Madrid, \\ Villaviciosa de Odón, 28670 Madrid, Spain \\ 3 Centro de Biología Molecular Severo Ochoa, CSIC-UAM, 28049 Madrid, Spain; pkidibule@cbm.csic.es (P.K.); \\ mfernandez@cbm.csic.es (M.F.-L.) \\ * Correspondence: fplou@icp.csic.es
}

Received: 5 April 2019; Accepted: 28 April 2019; Published: 30 April 2019

check for updates

\begin{abstract}
By controlled hydrolysis of chitosan or chitin with different enzymes, three types of chitooligosaccharides (COS) with MW between 0.2 and $1.2 \mathrm{kDa}$ were obtained: fully deacetylated ( $f d C O S)$, partially acetylated ( $p a C O S)$, and fully acetylated ( $f a C O S)$. The chemical composition of the samples was analyzed by high-performance anion exchange chromatography with pulsed amperometric detection (HPAEC-PAD) and MALDI-TOF mass spectrometry. The synthesized $f d C O S$ was basically formed by GlcN, $(\mathrm{GlcN})_{2},(\mathrm{GlcN})_{3}$, and $(\mathrm{GlcN})_{4}$. On the contrary, faCOS contained mostly GlcNAc, (GlcNAc) $)_{2}$ and (GlcNAc) $)_{3}$, while paCOS corresponded to a mixture of at least 11 oligosaccharides with different proportions of GlcNAc and GlcN. The anti-inflammatory activity of the three COS mixtures was studied by measuring their ability to reduce the level of TNF- $\alpha$ (tumor necrosis factor) in murine macrophages (RAW 264.7) after stimulation with a mixture of lipopolysaccharides (LPS). Only $f d C O S$ and $f a C O S$ were able to significantly reduce the production of tumor necrosis factor (TNF)- $\alpha$ at $6 \mathrm{~h}$ after stimulation with lipopolysaccharides.
\end{abstract}

Keywords: biocatalysis; glycosidases; chitinases; chitosanases; chitosan oligosaccharides; deacetylation degree; anti-inflammatory

\section{Introduction}

Chitin $\left[\left(\mathrm{C}_{8} \mathrm{H}_{13} \mathrm{O}_{5} \mathrm{~N}\right)_{n}\right]$ is a linear biopolymer of $\mathrm{N}$-acetyl-D-glucosamine (GlcNAc) moieties that gives toughness to the exoskeleton of arthropods (crustaceans, insects, etc.) and mollusks, as well as fungi cell walls [1,2]. The hydrolysis of chitin (and of its deacetylated product chitosan, more soluble than chitin) yields a series of chitooligosaccharides (COS) containing random GlcNAc and D-glucosamine (GlcN) units [3].

Three families of COS can be differentiated (Figure 1): fully acetylated chitooligosaccharides ( $f a C O S$ ) (formed exclusively by GlcNAc), partially acetylated chitooligosaccharides ( $p a C O S$ ) (composed of GlcN and GlcNAc), and fully deacetylated chitooligosaccharides ( $f d C O S$ ) (formed exclusively by GlcN) [4]. The bioactivity of COS is well reported [5-7], in particular their anti-inflammatory [8], neuroprotective [9], antibacterial [10], antiviral [11], antihypertensive [12] antiangiogenic [13], and antitumor [14] properties, among others. The size of COS (defined by the degree of polymerization, 
$\mathrm{DP})$, degree of deacetylation (DD) and pattern of acetylation (PA) exert a notable influence on their properties $[4,13,15,16]$.
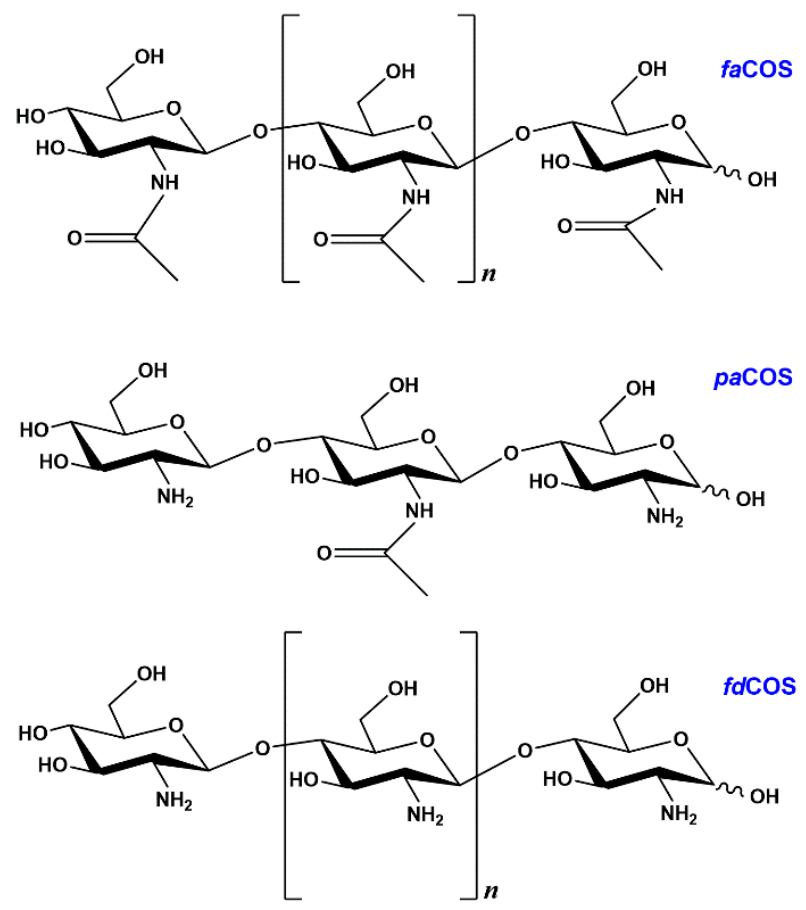

Figure 1. Structure of the three main types of chitooligosaccharides (COS): fully acetylated (faCOS), partially acetylated $(\mathrm{paCOS})$, and fully deacetylated ( $f \mathrm{COS})$.

Among the methodologies to perform the partial hydrolysis of chitin/chitosan into COS, the use of chitinolytic/chitosanolytic enzymes offer some advantages over physical, chemical, or electrochemical depolymerization [17]. Glycosidic enzymes require mild reaction conditions (moderate temperature and slightly acidic $\mathrm{pH}$ ), display high efficiency, and allow for control of the composition of the final product on the basis of enzyme specificity [4,18-22], which can also be altered by protein engineering techniques $[23,24]$. The enzymatic strategies are more environmentally friendly and generate less waste than the chemical methods $[3,25,26]$. The physicochemical properties of the starting chitosan also influence the composition of the resulting oligosaccharides [27,28].

For the hydrolysis of chitosan, chitosanases (EC 3.2.1.132) catalyze specifically the cleavage of $\beta(1 \rightarrow 4)$ glycosidic linkages between GlcN moieties [29-32]. However, other enzymes such as pectinases [33], cellulases [34], and proteases [35] also display chitosanolytic activity yielding COS. We have recently reported that a proteolytic preparation from Bacillus amyloliquefaciens (Neutrase 0.8L) is able to produce a mixture of COS that is highly enriched in $f d C O S$ [18].

Chitinases (EC 3.2.1.14) are hydrolytic enzymes involved in chitin decomposition that play an important role as control agents against pathogenic fungi in plants [36-38]. In recent research, we cloned chitinase Chit42 from fungus Trichoderma harzianum in Pichia pastoris to produce $3 \mathrm{~g} / \mathrm{L}$ using fed-batch fermentation, and its 3D structure was characterized [39]. This enzyme hydrolyzed chitin and chitosan with a low DD giving rise to mixtures enriched in $f a C O S$ and $p a C O S$, respectively. In general, the binding site of chitinases of fungal origin is substantially long and interacts with a minimum of five sugar units. The glycosyl-binding subsites are designated as $-3,-2,-1,+1$, and +2 , and the split occurs between the -1 and +1 sugar. A detailed structural analysis of Chit 42 indicated that this protein requires a GlcNAc residue in the substrate located at the -1 position for substrate hydrolysis.

In the present work, we have synthesized three COS mixtures enriched in $f d \mathrm{COS}, p a \mathrm{COS}$, and $f a \mathrm{COS}$. The samples were chemically characterized by chromatography and mass spectrometry. The effect of COS composition on anti-inflammatory properties was studied using a murine macrophage cell 
line (RAW 264.7). Although the anti-inflammatory activity of chitosan oligosaccharides is well reported [40-43], most of the works have been performed with COS mixtures not fully characterized in terms of DP, DD, or PA, probably due to the difficulties in the controlled synthesis and analysis of COS mixtures.

\section{Results and Discussion}

\subsection{Enzymatic Production and Characterization of fdCOS}

Based on previous work [18], we selected the commercial proteolytic preparation Neutrase 0.8L and a chitosan (CHIT600) with a high DD ( $>90 \%)$ to scale up the production of fully deacetylated COS (fdCOS). The reaction was carried out over $24 \mathrm{~h}$ with $1 \%(\mathrm{w} / \mathrm{v})$ chitosan at $\mathrm{pH} 5.0$ and $50{ }^{\circ} \mathrm{C}$. After this time, the enzyme and the remaining chitosan were eliminated by ultrafiltration with a $10 \mathrm{kDa}$ membrane. Then, the COS of high molecular weight were removed using a $1 \mathrm{kDa}$ cut-off membrane. The resulting solution was dialyzed over $0.1-0.5 \mathrm{kDa}$ cut-off tubing to eliminate the salts and other small contaminants, yielding a COS fraction with a molecular mass between 0.2 and $1.2 \mathrm{kDa}$. This fraction was further freeze-dried and characterized by high-performance anion exchange chromatography with pulsed amperometric detection (HPAEC-PAD) chromatography and MALDI-TOF mass spectrometry.

The HPAEC-PAD chromatogram of the COS obtained with Neutrase $0.8 \mathrm{~L}$-purified as described above-is represented in Figure 2. The chromatogram shows five main peaks corresponding to $f d \mathrm{COS}$, which was identified with the corresponding standards as GlcN $(1),(\mathrm{GlcN})_{2}(2),(\mathrm{GlcN})_{3}(3),(\mathrm{GlcN})_{4}(4)$, and $(\mathrm{GlcN})_{5}(5)$. In particular, chitobiose $\left[(\mathrm{GlcN})_{2}\right]$ and chitotriose $\left[(\mathrm{GlcN})_{3}\right]$ were the major products. Peaks marked with asterisks were not identified due to the lack of available standards.

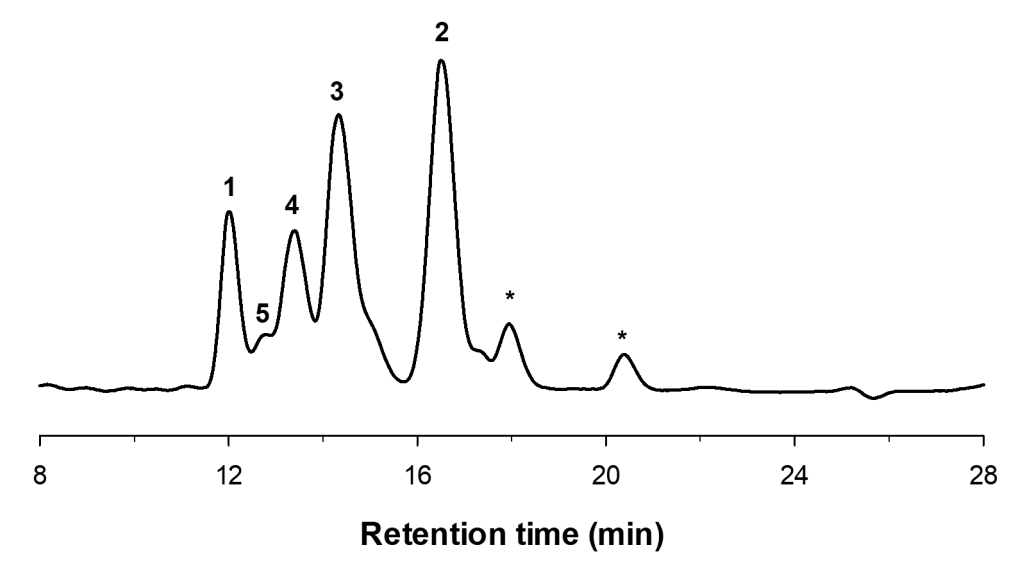

Figure 2. High-performance anion exchange chromatography with pulsed amperometric detection (HPAEC-PAD) chromatogram of the chitooligosaccharides produced by Neutrase $0.8 \mathrm{~L}$ using chitosan CHIT600. Reaction conditions: $1 \%(\mathrm{w} / \mathrm{v})$ chitosan, $10 \%(\mathrm{v} / \mathrm{v})$ Neutrase $0.8 \mathrm{~L}, 50{ }^{\circ} \mathrm{C}, 50 \mathrm{mM}$ ammonium acetate buffer $\mathrm{pH}$ 5.0, 24 h. Identified peaks: (1) GlcN; (2) $(\mathrm{GlcN})_{2} ;(3)(\mathrm{GlcN})_{3} ;(4)(\mathrm{GlcN})_{4} ;(5)(\mathrm{GlcN})_{5}$.

The MALDI-TOF spectrum of the COS mixture was in accordance with the chromatographic analysis since the main $\mathrm{m} / \mathrm{z}$ peaks corresponded to the molecular weight of the $f d \mathrm{COS}$. The main signals in the mass spectrum in positive mode belonged to the $\mathrm{M}+[\mathrm{Na}]^{+}$and $\mathrm{M}+[\mathrm{K}]^{+}$cations. Table 1 compiles the major $\mathrm{m} / \mathrm{z}$ signals and the assigned composition. Several $\mathrm{m} / \mathrm{z}$ values in agreement with partially acetylated COS ( $\mathrm{paCOS}$ ) appeared in the MS spectrum, with significantly lower intensity than the $f d C O S$. These $p a C O S$ probably corresponded to the unidentified peaks in the HPAEC-PAD analysis (Figure 2). However, their chemical structure could not be unequivocally assigned from the obtained data. The deacetylation degree of this $f d C O S$ sample must be between 95 and $100 \%$. 
Table 1. Main identified signals in the MALDI-TOF mass spectrum of the reaction between chitosan CHIT600 and Neutrase 0.8 L. Reaction conditions were as described in Figure 2.

\begin{tabular}{cc}
\hline$m / z$ & Assignation \\
\hline 180.0 & $\mathrm{GlcN}+\mathrm{H}^{+}$ \\
363.1 & $(\mathrm{GlcN})_{2}+\mathrm{Na}^{+}$ \\
$524.2 / 540.2$ & $(\mathrm{GlcN})_{3}+\mathrm{Na}^{+} / \mathrm{K}^{+}$ \\
$566.2 / 582.2$ & $(\mathrm{GlcN})_{2}-\mathrm{GlcNAc}+\mathrm{Na}^{+} / \mathrm{K}^{+}$ \\
$685.3 / 701.3$ & $(\mathrm{GlcN})_{4}+\mathrm{Na}^{+} / \mathrm{K}^{+}$ \\
$727.3 / 743.3$ & $(\mathrm{GlcN})_{3}-\mathrm{GlcNAc}+\mathrm{Na}^{+} / \mathrm{K}^{+}$ \\
$846.3 / 862.2$ & $(\mathrm{GlcN})_{5}+\mathrm{Na}^{+} / \mathrm{K}^{+}$ \\
$888.3 / 904.3$ & $(\mathrm{GlcN})_{4}-\mathrm{GlcNAc}+\mathrm{Na}^{+} / \mathrm{K}^{+}$ \\
1023.3 & $(\mathrm{GlcN})_{6}+\mathrm{K}^{+}$ \\
1049.4 & $(\mathrm{GlcN})_{5}-\mathrm{GlcNAc}+\mathrm{Na}^{+}$ \\
1210.4 & $(\mathrm{GlcN})_{6}-\mathrm{GlcNAc}+\mathrm{Na}^{+}$ \\
\hline
\end{tabular}

We calculated the efficiency of COS production with Neutrase $0.8 \mathrm{~L}$. Starting from $1 \mathrm{~g}$ chitosan CHIT600, and after all the purification steps, approximately $210 \mathrm{mg}$ of COS (mostly fully deacetylated) was obtained.

\subsection{Enzymatic Production and Characterization of faCOS}

For the production of $f a C O S$, the first step was the transformation of chitin flakes into colloidal chitin as previously described [39]. Chitinase Chit42 was used for the hydrolysis of chitin into fully acetylated chitooligosaccharides. Figure 3 illustrates the HPAEC-PAD chromatogram of the reaction mixture obtained with Chit42, which was purified as described in the Experimental Section. The presence of the $f a C O S$ GlcNAc (1), (GlcNAc) 2 (2), and (GlcNAc) 3 (3) was verified by using the corresponding standards. The deacetylation degree of this $f a C O S$ sample was between 0 and $5 \%$.

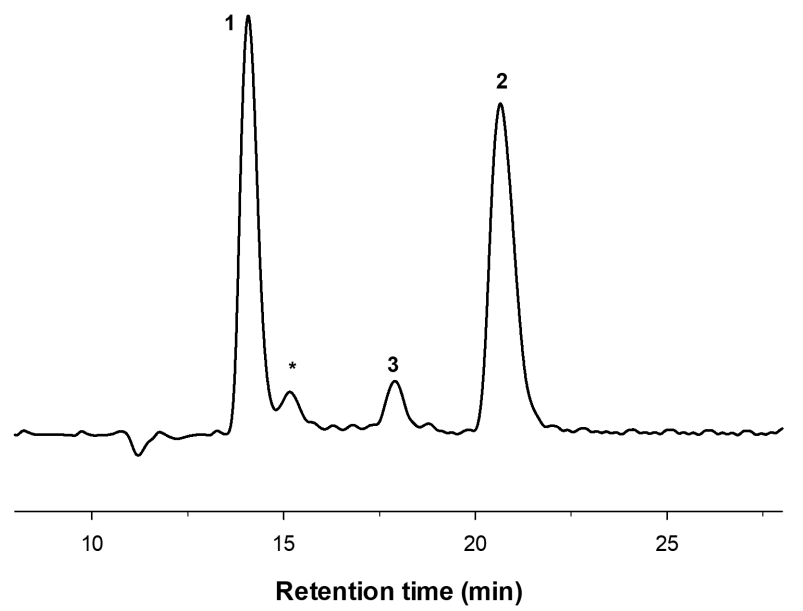

Figure 3. HPAEC-PAD chromatogram of the chitooligosaccharides obtained with chitinase Chit 42 employing chitin (colloid). Reaction conditions: 1\% (w/v) colloidal chitin, 10\% (v/v) chitinase, $70 \mathrm{mM}$ potassium phosphate $\mathrm{pH}$ 6.0. Identified peaks: (1) GlcNAc; (2) (GlcNAc) $)_{2}$ (3) (GlcNAc) 3 .

The MALDI-TOF spectrum of this mixture was simpler than that of $f d C O S$. Table 2 summarizes the main $\mathrm{m} / \mathrm{z}$ peaks and their assignations. The main signal in the mass spectrum corresponded to $(\mathrm{GlcNAc})_{2}$. It is worth noting that both the monomer GlcNAc and the trimer (GlcNAc) ${ }_{3}$ did not appear in the MS spectrum, probably due to bad ionization or low stability of the formed ions. In contrast, several peaks containing a GlcN moiety were present, which probably corresponded to the minor peaks detected in the HPAEC-PAD analysis, indicating that GlcN units favor MALDI ionization. Starting from $1 \mathrm{~g}$ of colloidal chitin, $75.8 \mathrm{mg}$ of the characterized $f a C O S$ was obtained. 
Table 2. Main identified signals in the MALDI-TOF mass spectrum of the reaction between chitinase Chit42 and colloidal chitin. Reaction conditions were as described in Figure 3.

\begin{tabular}{cc}
\hline$m / z$ & Assignation \\
\hline 405.2 & GlcN-GlcNAc $+\mathrm{Na}^{+}$ \\
$447.2 / 463.2$ & $(\mathrm{GlcNAc})_{2}+\mathrm{Na}^{+} / \mathrm{K}^{+}$ \\
$608.3 / 624.2$ & $\mathrm{GlcN}-(\mathrm{GlcNAc})_{2}+\mathrm{Na}^{+}$ \\
$769.3 / 785.2$ & $(\mathrm{GlcN})_{2}-(\mathrm{GlcNAc})_{2}+\mathrm{Na}^{+} / \mathrm{K}^{+}$ \\
811.3 & $\mathrm{GlcN}-(\mathrm{GlcNAc})_{3}+\mathrm{Na}^{+}$ \\
853.3 & $(\mathrm{GlcNAc})_{4}+\mathrm{Na}^{+}$ \\
\hline
\end{tabular}

\subsection{Enzymatic Production and Characterization of paCOS}

Chitosan QS1—with a lower DD (81\%) than CHIT600 (>90\%)—and chitinase Chit42, which requires a GlcNAc residue at -1 position [39], were used for the preparation of partially acetylated chitooligosaccharides ( $p a C O S$ ). The analysis of this family of COS is quite difficult due to the lack of commercial standards. Figure 4 illustrates the HPAEC-PAD chromatogram of the resulting mixture. At least 11 unidentified peaks were detected.

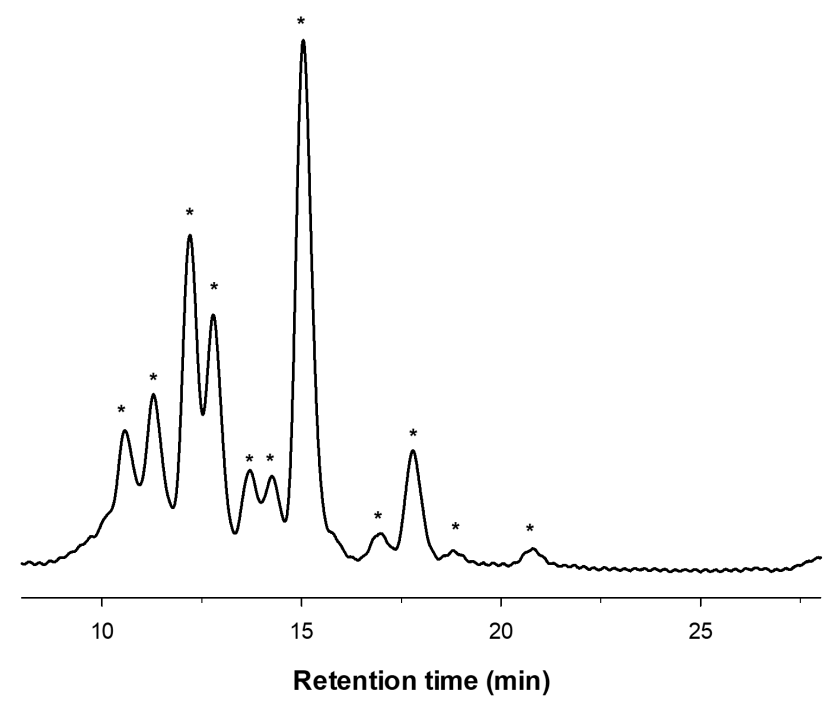

Figure 4. HPAEC-PAD chromatogram of the chitooligosaccharides produced by chitinase Chit42 using chitosan QS1 as substrate. Reaction conditions: 1\% (w/v) chitosan, 10\% (v/v) chitinase Chit 42 , $70 \mathrm{mM}$ potassium phosphate $\mathrm{pH}$ 6.0.

Table 3 summarizes the main $\mathrm{m} / \mathrm{z}$ peaks detected in the MALDI-TOF spectrum and the proposed composition. However, the chemical structure of these compounds cannot be inferred from the mass spectrometry data. Since chitinase Chit 42 only cleaves chitosan when a GlcNAc residue is located at the -1 position, the synthesized COS should present a GlcNAc at the reducing end. Table 3 includes COS containing up to nine residues with GlcN as the main component, which correlates well with the degree of deacetylation of chitosan QS1. After the purification steps, starting from $500 \mathrm{mg}$ of chitosan QS1, $18 \mathrm{mg}$ of $p a C O S$ was isolated. The lower yield obtained in comparison with $f d C O S$ and $f a C O S$ was probably a consequence of the requirement of Chit 42 for a GlcNAc at -1 position and the presence of a high proportion of GlcN (81\%) in chitosan QS1. 
Table 3. Main identified signals in the MALDI-TOF mass spectrum of the reaction between chitosan QS1 and chitinase Chit42. Reaction conditions were as described in Figure 4.

\begin{tabular}{cc}
\hline$m / z$ & Assignation \\
\hline $405.2 / 421.2$ & GlcN-GlcNAc $+\mathrm{Na}^{+} / \mathrm{K}^{+}$ \\
$447.2 / 463.2$ & $(\mathrm{GlcNAc})_{2}+\mathrm{Na}^{+} / \mathrm{K}^{+}$ \\
$566.3 / 582.2$ & $(\mathrm{GlcN})_{2}-\mathrm{GlcNAc}+\mathrm{Na}^{+} / \mathrm{K}^{+}$ \\
$608.3 / 624.3$ & $\mathrm{GlcN}-(\mathrm{GlcNAc})_{2}+\mathrm{Na}^{+} / \mathrm{K}^{+}$ \\
$727.3 / 743.3$ & $(\mathrm{GlcN})_{3}-\mathrm{GlcNAc}+\mathrm{Na}^{+} / \mathrm{K}^{+}$ \\
$769.3 / 785.3$ & $(\mathrm{GlcN})_{2}-(\mathrm{GlcNAc})_{2}+\mathrm{Na}^{+} / \mathrm{K}^{+}$ \\
$811.3 / 827.3$ & $\mathrm{GlcN}-(\mathrm{GlcNAc})_{3}+\mathrm{Na}^{+} / \mathrm{K}^{+}$ \\
$888.4 / 904.3$ & $(\mathrm{GlcN})_{4}-\mathrm{GlcNAc}+\mathrm{Na}^{+} / \mathrm{K}^{+}$ \\
$930.4 / 946.3$ & $(\mathrm{GlcN})_{3}-(\mathrm{GlcNAc})_{2}+\mathrm{Na}^{+} / \mathrm{K}^{+}$ \\
$1049.4 / 1065.4$ & $(\mathrm{GlcN})_{5}-\mathrm{GlcNAc}+\mathrm{Na}^{+} / \mathrm{K}^{+}$ \\
$1091.4 / 1107.4$ & $(\mathrm{GlcN})_{4}-(\mathrm{GlcNAc})_{2}+\mathrm{Na}^{+} / \mathrm{K}^{+}$ \\
$1133.4 / 1149.4$ & $(\mathrm{GlcN})_{3}-(\mathrm{GlcNAc})_{3}+\mathrm{Na}^{+} / \mathrm{K}^{+}$ \\
$1210.4 / 1226.4$ & $(\mathrm{GlcN})_{6}-\mathrm{GlcNAc}+\mathrm{Na}^{+} / \mathrm{K}^{+}$ \\
$1252.5 / 1268.4$ & $(\mathrm{GlcN})_{5}-(\mathrm{GlcNAc})_{2}+\mathrm{Na}^{+} / \mathrm{K}^{+}$ \\
$1294.5 / 1310.4$ & $(\mathrm{GlcN})_{4}-(\mathrm{GlcNAc})_{3}+\mathrm{Na}^{+} / \mathrm{K}^{+}$ \\
$1413.5 / 1429.5$ & $(\mathrm{GlcN})_{6}-(\mathrm{GlcNAc})_{2}+\mathrm{Na}^{+} / \mathrm{K}^{+}$ \\
$1532.6 / 1548.5$ & $(\mathrm{GlcN})_{8}-\mathrm{GlcNAc}+\mathrm{Na}^{+} / \mathrm{K}^{+}$ \\
\hline
\end{tabular}

\subsection{Anti-Inflammatory Activity of $f d C O S, f a C O S$, and paCOS}

Inflammation plays an important role in the development of a series of pathologies including autoimmune diseases and cancer [44]. The anti-inflammatory activity of the three samples of COS previously obtained was assessed by measuring their ability to reduce the level of TNF- $\alpha$ (tumor necrosis factor) in murine macrophages (RAW 264.7) after stimulation with a mixture of lipopolysaccharides (LPS). TNF- $\alpha$ is a cytokine involved in systemic inflammation and one of the cytokines released by activated macrophages during the acute phase reaction of inflammation [45].

Three concentrations of COS were tested in a multi-well plate: 100, 250, and 500 ng per well. The ELISA methodology for the detection of TNF- $\alpha$ was properly validated through the accuracy of the standard curve obtained, which allowed the quantification of samples with a TNF- $\alpha$ concentration between 30 and $1000 \mathrm{pg} / \mathrm{mL}$. The amount of TNF- $\alpha$ was measured at 2 and $6 \mathrm{~h}$ after incubation with LPS (10 ng/well). To discard the possible inflammatory effect of the compounds, the cells were also exposed to the three COS samples in the absence of LPS. However, no significant effect was observed in samples supplemented only with $f d \mathrm{COS}, f a \mathrm{COS}$, or $p a \mathrm{COS}$ (data not shown). After the stimulations, both the culture supernatants and the cells were collected at 2 and $6 \mathrm{~h}$.

Figure 5 shows the TNF- $\alpha$ concentration in the supernatants after 2 and $6 \mathrm{~h}$ stimulated with $f d \mathrm{COS}$, $f a \mathrm{COS}$, and $p a \mathrm{COS}$ (at the three concentrations) in combination with $10 \mathrm{ng}$ LPS. The results of the control experiment of cells stimulated only with LPS are also included in the figure. As illustrated in Figure 5, the TNF- $\alpha$ concentration tended to increase over time for most samples. The highest TNF- $\alpha$ concentration $(1575 \mathrm{pg} / \mathrm{mL})$ was obtained after $6 \mathrm{~h}$ post-stimulation with $10 \mathrm{ng}$ of LPS per well.

The three types of COS were able to decrease the production of TNF- $\alpha$ at $6 \mathrm{~h}$ after stimulation with LPS. The highest effect was obtained using $250 \mathrm{ng} /$ well (Figure 5). It is worth noting that $f d C O S$ exhibited a negligible anti-inflammatory effect at concentrations of 100 and $500 \mathrm{ng} /$ well after a 2-h incubation, but this effect increased significantly at $6 \mathrm{~h}$. This relates well with our preliminary results with $f d \operatorname{COS}$ [18]. In contrast, $p a C O S$ (except for $100 \mathrm{ng} /$ well) and $f a C O S$ displayed a more stable effect between 2 and $6 \mathrm{~h}$. These results could be indicating a critical role of the acetamido group of COS in their properties. However, only the $f d \operatorname{COS}$ and $f a C O S$ at a concentration of $250 \mathrm{ng} /$ well and after $6 \mathrm{~h}$ incubation displayed a statistically significant anti-inflammatory effect. 

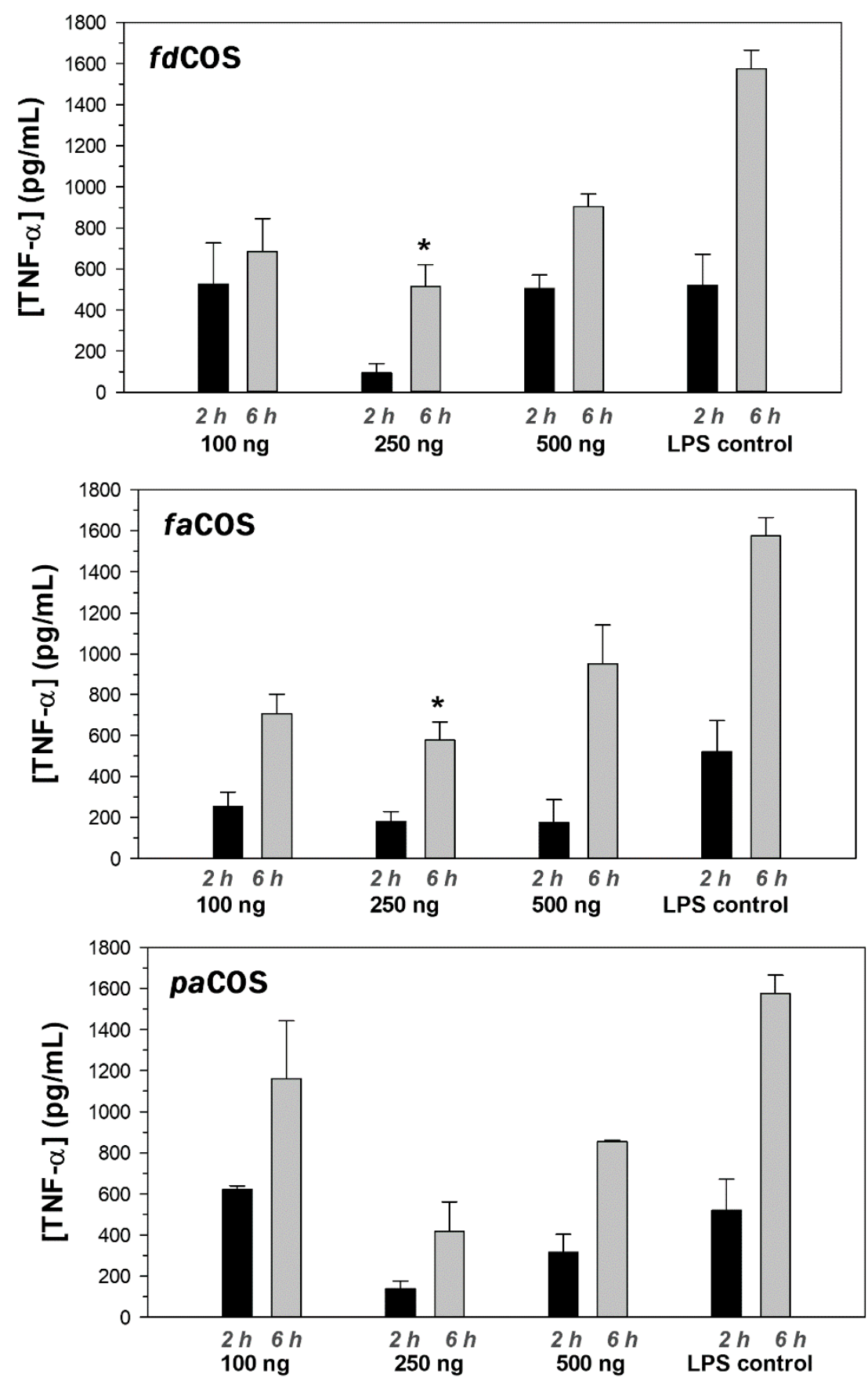

Figure 5. Tumor necrosis factor-alpha (TNF- $\alpha$ ) concentration in the supernatants from cells stimulated with fdCOS, faCOS, and paCOS (at 100, 250, and $500 \mathrm{ng}$ per well) in combination with $10 \mathrm{ng}$ lipopolysaccharide (LPS) per well. Graphs show the amount of TNF- $\alpha$ at 2 and $6 \mathrm{~h}$ post-stimulation. The data is expressed as the mean $\pm \mathrm{SD}\left({ }^{*} p<0.05\right.$ vs. LPS control).

These results correlate well with previous works that analyzed the anti-inflammatory activity of COS. Yoon et al. reported the attenuation of secretion of TNF- $\alpha$ and IL- 6 induced by LPS upon incubation with COS, demonstrating that the expression of these cytokines was regulated by COS at the transcription level [41]. However, the authors employed a commercial COS that was not fully characterized (MW < 10000; 90-95\% DD). The dependence of anti-inflammatory activity on the molecular weight of COS was studied by Fernandes et al. [8] and Pangestuti et al. [46], concluding that COS of a low molecular weight were the most efficient. Sánchez et al. reported that a mixture 
with a similar content of deacetylated and monoacetylated HMW COS (5-10 kDa) produced the best anti-inflammatory effects [47].

Our results correlate well with those of Lee et al. [48]. They demonstrated that COS with $90 \% \mathrm{~N}$-deacetylation (90-COS) displayed a higher anti-inflammatory effect than COS with $50 \%$ $\mathrm{N}$-deacetylation (50-COS, more related to $\mathrm{paCOS}$ ); interestingly, the 90-COS with a molecular mass between 5 and $10 \mathrm{kDa}$ showed the highest inhibition activity.

In conclusion, the secretion of TNF- $\alpha$ decreased during the first $6 \mathrm{~h}$ in macrophages treated with the three COS mixtures in comparison with macrophages stimulated with LPS only. These results confirm the inhibitory effect of COS against inflammation, which confirms their potential as ingredients in functional foods and nutraceutical and pharmaceutical preparations.

\section{Materials and Methods}

\subsection{Enzymes and Reagents}

Neutrase 0.8 L was kindly donated by Novozymes A/S (Bagsværd, Denmark). The expression and production of Chit42 (chitinase from Trichoderma harzianum) by Pichia pastoris was performed as previously described [39]. Chitosan CHIT600 from shrimp shells (600-800 kDa, DD > 90\%) was purchased from Acros Organics (Geel, Belgium). Chitosan QS1 from Paralomis granulosa (98 kDa, $81 \%$ DD) was supplied by InFiQus (Madrid, Spain). Chitin (coarse flakes, DD $\leq 5 \%$ ) from shrimp shells and N-acetyl-glucosamine (GlcNAc) were from Sigma-Aldrich (Madrid, Spain). Chitobiose $\left[(\mathrm{GlcN})_{2}\right]$, chitotriose $\left[(\mathrm{GlcN})_{3}\right]$, chitotetraose $\left[(\mathrm{GlcN})_{4}\right], \mathrm{N}, \mathrm{N}^{\prime}$-di-N-acetyl-glucosamine $\left[(\mathrm{GlcNAc})_{2}\right]$, and $\mathrm{N}, \mathrm{N}^{\prime}, \mathrm{N}^{\prime \prime}$-tri-N-acetyl-glucosamine $\left[(\mathrm{GlcNAc})_{3}\right]$ were acquired from Carbosynth Ltd. (Compton, Berkshire, UK). All other reagents were of the highest purity grade available.

\subsection{Preparation of Colloidal Chitin}

Colloidal chitin was prepared following the method of Jeuniaux [49]. In particular, $10 \mathrm{~g}$ of chitin and $175 \mathrm{~mL}$ of $10 \mathrm{M} \mathrm{HCl}$ were stirred for $16 \mathrm{~h}$ at $4{ }^{\circ} \mathrm{C}$. Then, the mixture was filtered using thick glass fibers and mixed with $1 \mathrm{~L}$ of ethanol. After $16 \mathrm{~h}$ at $4{ }^{\circ} \mathrm{C}$, the precipitated chitin floccules were separated by centrifugation at $5000 \times \mathrm{g}$ for $10 \mathrm{~min}$ and washed with distilled water. Finally, $200 \mathrm{~mL}$ of potassium phosphate buffer $(70 \mathrm{mM}, \mathrm{pH} 6.0)$ was added to the pellet. To determine the concentration of colloidal chitin, $1 \mathrm{~mL}$ of solution was frozen at $-70^{\circ} \mathrm{C}$, lyophilized, and weighed.

\subsection{COS Production and Purification}

Chitooligosaccharides with different deacetylation degrees were produced by different combinations of enzymes and substrates based on previous works $[18,39]$. The reaction conditions for the production of each type of COS are summarized in Table 4.

Table 4. Experimental conditions for the preparation of COS samples.

\begin{tabular}{cccc}
\hline Enzyme & Substrate & Reaction Conditions & Main Products \\
\hline Chit42 & Colloidal chitin & $35^{\circ} \mathrm{C}, \mathrm{pH} 6.0$ & $f a$ COS \\
Chit42 & Chitosan QS1 & $35^{\circ} \mathrm{C}, \mathrm{pH} 6.0$ & $\mathrm{paCOS}$ \\
Neutrase $0.8 \mathrm{~L}$ & Chitosan CHIT600 & $50^{\circ} \mathrm{C}, \mathrm{pH} 5.0$ & $f d \mathrm{COS}$ \\
\hline
\end{tabular}

Reactions were carried out in a final volume of $40 \mathrm{~mL}$ containing $4 \mathrm{~mL}$ of enzyme solution and $36 \mathrm{~mL}$ of $1 \%(\mathrm{w} / \mathrm{w})$ substrate dissolved properly in ammonium acetate at the optimal $\mathrm{pH}$ for the reaction. The formation of COS was followed by HPAEC-PAD until the hydrolysis was complete. Samples were filtrated through a paper filter to remove any insoluble particles and further purified by a series of membranes. First, the reaction mixture was fractionated using a $50 \mathrm{~mL}$ Amicon system with a $10 \mathrm{kDa}$ cut-off membrane. This step separated the enzyme and the unreacted high molecular weight chitosan from the chitooligosaccharides. Then, the fraction of $\operatorname{COS}(<10 \mathrm{kDa})$ was further fractionated 
with a $1 \mathrm{kDa}$ cut-off membrane. The fraction of COS whose MW was lower than $1 \mathrm{kDa}$ was then dialyzed with a 0.1-0.5 kDa membrane (Biotech Cellulose Ester Dialysis Membrane, Spectra/Por, Fisher Scientific, Madrid, Spain) to remove the salts and small contaminants from the sample, yielding a COS fraction with a MW between 0.1 and $1 \mathrm{kDa}$. This fraction was lyophilized, analyzed by HPAEC-PAD and MALDI-TOF, and used for bioactivity assays.

\subsection{COS Characterization by HPAEC-PAD and MALDI-TOF}

COS samples were analyzed at $30^{\circ} \mathrm{C}$ by HPAEC-PAD on a chromatograph ICS3000 (Dionex, Thermo Fischer Scientific Inc., Waltham, MA, USA) formed by a gradient pump (model SP), an electrochemical detector consisting of a working electrode $(\mathrm{Au})$ and a reference electrode $(\mathrm{Ag} / \mathrm{AgCl})$, and a AS-HV autosampler. The column was an anion exchange Carbo-Pack PA-200 (Dionex, $4 \times 250 \mathrm{~mm})$ connected to a CarboPac PA-200 guard column $(4 \times 50 \mathrm{~mm})$. A post-column delivery system (PC10) pumped $200 \mathrm{mM} \mathrm{NaOH}$ to enhance the detector response. The mobile phase was $1 \mathrm{mM}$ $\mathrm{NaOH}$ at a flow rate of $0.3 \mathrm{~mL} / \mathrm{min}$ for $20 \mathrm{~min}$, followed by a gradient from 0 to $320 \mathrm{mM}$ sodium acetate/100 $\mathrm{mM} \mathrm{NaOH}$ in $10 \mathrm{~min}$, that was kept for another $10 \mathrm{~min}$. Equilibration of the column to the initial conditions was made for $40 \mathrm{~min}$. The chromatograms were analyzed using Chromeleon software. The identification and quantification of the different carbohydrates were done based on commercial standards when available.

The molecular size of COS was analyzed by MALDI-TOF mass spectrometry using Ultraflex III TOF/TOF equipment (Bruker, Billerica, MA, USA) equipped with a NdYAG laser. The spectra were acquired in positive reflector mode in the mass interval 40-5000 Da, employing $20 \mathrm{mg} / \mathrm{mL}$ 2,5-dihydroxybenzoic acid (DHB) in acetonitrile: $\mathrm{H}_{2} \mathrm{O}(3: 7)(\mathrm{v} / \mathrm{v})$ as matrix and external calibration. The samples were mixed with the DHB matrix in a $4: 1(\mathrm{v} / \mathrm{v})$ ratio and $0.5 \mu \mathrm{L}$ was injected.

\subsection{Anti-Inflammatory Activity of COS}

RAW 264.7 cells were cultured in DMEM (Dulbecco's Modified Eagle's medium) supplemented with $10 \%$ FBS (fetal bovine serum) and 1\% penicillin/streptomycin. Cells were counted with a Neubauer chamber in order to seed a concentration of 2 million cells per well. Each of the compounds was tested in duplicate at three different concentrations: 500, 250, and $100 \mathrm{ng} /$ well. A mixture of lipopolysaccharides (LPS, potent immune cell activator) at a concentration of $10 \mathrm{ng}$ per well was used as a positive control, and PBS (phosphate buffered saline) was used as a negative control and added to the wells in the same volume as the rest of the compounds. The cells were also exposed to the three chitooligosaccharides (without LPS) as a control for the inflammatory effect of the compounds. After the stimulations, both the culture supernatants and the cells were collected at 2 and $6 \mathrm{~h}$. Samples were frozen and kept at $-80^{\circ} \mathrm{C}$ until analysis.

The quantification of anti-TNF- $\alpha$ antibodies in culture supernatants was assessed by ELISA using a murine TNF- $\alpha$ ELISA kit (Diaclone, Besançon, France) following the protocol provided by the manufacturer. Samples were diluted 1:2 $(v / v)$ in an appropriate buffer (provided by the kit) and $100 \mu \mathrm{L}$ was added in duplicate to the plate. Serial dilutions of the standard were made to provide a concentration range from 1000 to $31.25 \mathrm{pg} / \mathrm{mL}$, and $100 \mu \mathrm{L}$ was added per well in duplicate to the ELISA plate. Biotinylated anti-murine TNF- $\alpha$ antibody was properly diluted according to the manufacturer's protocol and $50 \mu \mathrm{L}$ was added to each well. Plates were sealed and incubated at room temperature for $3 \mathrm{~h}$. After incubation, plates were washed three times with the wash buffer provided with the kit. Streptavidin-Horseradish Peroxidase (HRP) solution $(100 \mu \mathrm{L})$ was added for the detection of the biotinylated detection antibody and plates were incubated at room temperature for $30 \mathrm{~min}$. Then, $100 \mu \mathrm{L}$ of ready-to-use 3,3',5,5'-Tetramethylbenzidine (TMB) substrate solution was transferred into each well. Plates were incubated in the dark at room temperature $(10 \mathrm{~min})$ for color development. To stop the color reaction, $50 \mu \mathrm{L}$ of $2 \mathrm{~N} \mathrm{H}_{2} \mathrm{SO}_{4}$ was added. The optical density (OD) for each well was measured with a microplate reader set to $450 \mathrm{~nm}$. 
Data were expressed as the mean \pm standard deviation (SD) with $n=2$. Brown-Forsythe test and post-hoc Games-Howell method were used to find differences with respect to the LPS control. Statistical analysis was performed with IBM ${ }^{\circledR}$ SPSS $^{\circledR}$ Statistics v25 and differences were considered significant when $p<0.05$.

Author Contributions: F.J.P., M.F.-L. and A.O.B. conceived and designed the experiments; P.S.-M. and N.M. performed most of the experiments; P.K. and M.F.-L. contributed with Chit42 production; L.F.-A. contributed with chromatographic methods for COS analysis; F.J.P. and P.S.-M. wrote the paper, which was improved by the rest of the authors.

Funding: This work was supported by the Fundación Ramón Areces (XIX Call of Research Grants in Life and Materials Sciences) and the Spanish Ministry of Economy and Competitiveness (Grants BIO2016-76601-C3-1-R and BIO2016-76601-C3-3-R). We also acknowledge the institutional grant from Ramon Areces Foundation to the Centre of Molecular Biology "Severo Ochoa". The European Union's Horizon 2020 program also financed this work (Blue Growth: Unlocking the potential of Seas and Oceans; grant agreement No. 634486; INMARE). We thank the support of the EU COST-Action CM1303 on Systems Biocatalysis.

Acknowledgments: We thank Laura Córdoba and Miguel Angel Llamas (Diomune S.L.) for their help in the analysis of the anti-inflammatory properties. We thank Ramiro Martinez (Novozymes A/S) for supplying Neutrase $0.8 \mathrm{~L}$ and for relevant suggestions. We are also grateful for the support of the publication fee by the CSIC Open Access Publication Support Initiative through its Unit of Information Resources for Research (URICI).

Conflicts of Interest: The authors declare no conflict of interest.

\section{References}

1. Hamed, I.; Özogul, F.; Regenstein, J.M. Industrial applications of crustacean by-products (chitin, chitosan, and chitooligosaccharides): A review. Trends Food Sci. Technol. 2016, 48, 40-50. [CrossRef]

2. Gortari, M.C.; Hours, R.A. Biotechnological processes for chitin recovery out of crustacean waste: A mini-review. Electron. J. Biotechnol. 2013, 16, 1-14.

3. Kumar, M.; Brar, A.; Vivekanand, V.; Pareek, N. Bioconversion of chitin to bioactive chitooligosaccharides: Amelioration and coastal pollution reduction by microbial resources. Mar. Biotechnol. 2018, 20, $269-281$. [CrossRef] [PubMed]

4. Hamer, S.N.; Cord-Landwehr, S.; Biarnés, X.; Planas, A.; Waegeman, H.; Moerschbacher, B.M.; Kolkenbrock, S. Enzymatic production of defined chitosan oligomers with a specific pattern of acetylation using a combination of chitin oligosaccharide deacetylases. Sci. Rep. 2015, 5, 8716. [CrossRef] [PubMed]

5. Liaqat, F.; Eltem, R. Chitooligosaccharides and their biological activities: A comprehensive review. Carbohydr. Polym. 2018, 184, 243-259. [CrossRef]

6. Je, J.Y.; Kim, S.K. Chitooligosaccharides as potential nutraceuticals: production and bioactivities. Adv. Food Nutr. Res. 2012, 65, 321-336.

7. Xia, W.; Liu, P.; Zhang, J.; Chen, J. Biological activities of chitosan and chitooligosaccharides. Food Hydrocolloids 2011, 25, 170-179. [CrossRef]

8. Fernandes, J.C.; Spindola, H.; de Sousa, V.; Santos-Silva, A.; Pintado, M.E.; Malcata, F.X.; Carvalho, J.E. Anti-inflammatory activity of chitooligosaccharides in vivo. Mar. Drugs 2010, 8, 1763-1768. [CrossRef]

9. Jiang, M.; Guo, Z.; Wang, C.; Yang, Y.; Liang, X.; Ding, F. Neural activity analysis of pure chito-oligomer components separated from a mixture of chitooligosaccharides. Neurosci. Lett. 2014, 581, 32-36. [CrossRef]

10. Wu, S.-J.; Pan, S.-K.; Wang, H.-B.; Wu, J.-H. Preparation of chitooligosaccharides from cicada slough and their antibacterial activity. Int. J. Biol. Macromol. 2013, 62, 348-351. [CrossRef]

11. Artan, M.; Karadeniz, F.; Karagozlu, M.Z.; Kim, M.M.; Kim, S.K. Anti-HIV-1 activity of low molecular weight sulfated chitooligosaccharides. Carbohydr. Res. 2010, 345, 656-662. [CrossRef]

12. Huang, R.; Mendis, E.; Kim, S.K. Improvement of ACE inhibitory activity of chitooligosaccharides (COS) by carboxyl modification. Bioorg. Med. Chem. 2005, 13, 3649-3655. [CrossRef] [PubMed]

13. Wu, H.; Aam, B.B.; Wang, W.; Norberg, A.L.; Sørlie, M.; Eijsink, V.G.H.; Du, Y. Inhibition of angiogenesis by chitooligosaccharides with specific degrees of acetylation and polymerization. Carbohydr. Polym. 2012, 89, 511-518. [CrossRef]

14. Kim, E.K.; Je, J.Y.; Lee, S.J.; Kim, Y.S.; Hwang, J.W.; Sung, S.H.; Moon, S.H.; Jeon, B.T.; Kim, S.K.; Jeon, Y.J.; et al. Chitooligosaccharides induce apoptosis in human myeloid leukemia HL-60 cells. Bioorg. Med. Chem. Lett. 2012, 22, 6136-6138. [CrossRef] [PubMed] 
15. Mengíbar, M.; Mateos-Aparicio, I.; Miralles, B.; Heras, A. Influence of the physico-chemical characteristics of chito-oligosaccharides (COS) on antioxidant activity. Carbohydr. Polym. 2013, 97, 776-782. [CrossRef]

16. Yarullina, L.G.; Sorokan, A.V.; Burkhanova, G.F.; Cherepanova, E.A.; Maksimov, I.V. Influence of chitooligosaccharides with different acetylation degrees on the $\mathrm{H}_{2} \mathrm{O}_{2}$ content and the activity of pathogenesis-related proteins in potato plants infected with Phytophthora infestans. Appl. Biochem. Microbiol. 2018, 54, 528-534. [CrossRef]

17. Liang, S.; Sun, Y.X.; Dai, X.L. A review of the preparation, analysis and biological functions of chitooligosaccharide. Int. J. Mol. Sci. 2018, 19, 2197. [CrossRef] [PubMed]

18. Santos-Moriano, P.; Fernandez-Arrojo, L.; Mengibar, M.; Belmonte-Reche, E.; Peñalver, P.; Acosta, F.N.; Ballesteros, A.O.; Morales, J.C.; Kidibule, P.; Fernandez-Lobato, M.; et al. Enzymatic production of fully deacetylated chitooligosaccharides and their neuroprotective and anti-inflammatory properties. Biocatal. Biotransform. 2018, 36, 57-67. [CrossRef]

19. de Araujo, N.K.; de Assis, C.F.; Dos Santos, E.S.; de Macedo, G.R.; de Farias, L.F.; Arimateia, H., Jr.; de Freitas Fernandes Pedrosa, M.; Pagnoncelli, M.G. Production of enzymes by Paenibacillus chitinolyticus and Paenibacillus ehimensis to obtain chitooligosaccharides. Appl. Biochem. Biotechnol. 2013, 170, 292-300. [CrossRef] [PubMed]

20. Plou, F.J.; Gómez de Segura, A.; Ballesteros, A. Application of glycosidases and transglycosidases for the synthesis of oligosaccharides. In Industrial enzymes: Structure, Function and Application; Polaina, J., MacCabe, A.P., Eds.; Springer: New York, NY, USA, 2007; pp. 141-157.

21. Fernandez-Arrojo, L.; Marin, D.; Gomez de Segura, A.; Linde, D.; Alcalde, M.; Gutierrez-Alonso, P.; Ghazi, I.; Plou, F.J.; Fernandez-Lobato, M.; Ballesteros, A. Transformation of maltose into prebiotic isomaltooligosaccharides by a novel alpha-glucosidase from Xantophyllomyces dendrorhous. Process Biochem. 2007, 42, 1530-1536. [CrossRef]

22. Linde, D.; Rodriguez-Colinas, B.; Estevez, M.; Poveda, A.; Plou, F.J.; Fernandez-Lobato, M. Analysis of neofructooligosaccharides production mediated by the extracellular beta-fructofuranosidase from Xanthophyllomyces dendrorhous. Bioresour. Technol. 2012, 109, 123-130. [CrossRef]

23. Liu, S.; Shao, S.; Li, L.; Cheng, Z.; Tian, L.; Gao, P.; Wang, L. Substrate-binding specificity of chitinase and chitosanase as revealed by active-site architecture analysis. Carbohydr. Res. 2015, 418, 50-56. [CrossRef]

24. de Abreu, M.; Alvaro-Benito, M.; Sanz-Aparicio, J.; Plou, F.J.; Fernandez-Lobato, M.; Alcalde, M. Synthesis of 6-kestose using an efficient beta-fructofuranosidase engineered by directed evolution. Adv. Synth. Catal. 2013, 355, 1698-1702. [CrossRef]

25. Song, J.Y.; Alnaeeli, M.; Park, J.K. Efficient digestion of chitosan using chitosanase immobilized on silica-gel for the production of multisize chitooligosaccharides. Process Biochem. 2014, 49, 2107-2113. [CrossRef]

26. Alcalde, M.; Ferrer, M.; Plou, F.J. Environmental biocatalysis: From remediation with enzymes to novel green processes. Biocatal. Biotransform. 2007, 25, 113. [CrossRef]

27. Olicón-Hernández, D.R.; Vázquez-Landaverde, P.A.; Cruz-Camarillo, R.; Rojas-Avelizapa, L.I. Comparison of chito-oligosaccharide production from three different colloidal chitosans using the endochitonsanolytic system of Bacillus thuringiensis. Prep. Biochem. Biotechnol. 2017, 47, 116-122. [CrossRef] [PubMed]

28. Santos-Moriano, P.; Woodley, J.M.; Plou, F.J. Continuous production of chitooligosaccharides by an immobilized enzyme in a dual-reactor system. J. Mol. Catal. B Enzym. 2016, 133, 211-217. [CrossRef]

29. Li, H.; Fei, Z.; Gong, J.; Yang, T.; Xu, Z.; Shi, J. Screening and characterization of a highly active chitosanase based on metagenomic technology. J. Mol. Catal. B Enzym. 2015, 111, 29-35. [CrossRef]

30. Thadathil, N.; Velappan, S.P. Recent developments in chitosanase research and its biotechnological applications: A review. Food Chem. 2014, 150, 392-399. [CrossRef]

31. Sinha, S.; Chand, S.; Tripathi, P. Production, purification and characterization of a new chitosanase enzyme and improvement of chitosan pentamer and hexamer yield in an enzyme membrane reactor. Biocatal. Biotransform. 2014, 32, 208-213. [CrossRef]

32. Santos-Moriano, P.; Kidibule, P.E.; Alleyne, E.; Ballesteros, A.O.; Heras, A.; Fernandez-Lobato, M.; Plou, F.J. Efficient conversion of chitosan into chitooligosaccharides by a chitosanolytic activity from Bacillus thuringiensis. Process Biochem. 2018, 73, 102-108. [CrossRef]

33. Kittur, F.S.; Vishu Kumar, A.B.; Varadaraj, M.C.; Tharanathan, R.N. Chitooligosaccharides—Preparation with the aid of pectinase isozyme from Aspergillus niger and their antibacterial activity. Carbohydr. Res. 2005, 340, 1239-1245. [CrossRef] 
34. Xia, W.; Liu, P.; Liu, J. Advance in chitosan hydrolysis by non-specific cellulases. Bioresour. Technol. 2008, 99, 6751-6762. [CrossRef] [PubMed]

35. Kumar, A.B.V.; Tharanathan, R.N. A comparative study on depolymerization of chitosan by proteolytic enzymes. Carbohydr. Polym. 2004, 58, 275-283.

36. Oyeleye, A.; Normi, Y.M. Chitinase: Diversity, limitations, and trends in Engineering for suitable applications. Biosci. Rep. 2018, 38, 4. [CrossRef]

37. Moon, C.; Seo, D.J.; Song, Y.S.; Hong, S.H.; Choi, S.H.; Jung, W.J. Antifungal activity and patterns of N-acetyl-chitooligosaccharide degradation via chitinase produced from Serratia marcescens PRNK-1. Microb. Pathog. 2017, 113, 218-224. [CrossRef] [PubMed]

38. Sha, L.; Shao, E.; Guan, X.; Huang, Z. Purification and partial characterization of intact and truncated chitinase from Bacillus thuringiensis HZP7 expressed in Escherichia coli. Biotechnol. Lett. 2016, 38, 279-284. [CrossRef]

39. Kidibule, P.E.; Santos-Moriano, P.; Jiménez-Ortega, E.; Ramírez-Escudero, M.; Limón, M.C.; Remacha, M.; Plou, F.J.; Sanz-Aparicio, J.; Fernández-Lobato, M. Use of chitin and chitosan to produce new chitooligosaccharides by chitinase Chit42: Enzymatic activity and structural basis of protein specificity. Microb. Cell Fact. 2018, 17, 47. [CrossRef] [PubMed]

40. Wei, P.; Ma, P.; Xu, Q.S.; Bai, Q.H.; Gu, J.G.; Xi, H.; Du, Y.G.; Yu, C. Chitosan oligosaccharides suppress production of nitric oxide in lipopolysaccharide-induced N9 murine microglial cells in vitro. Glycoconjugate J. 2012, 29, 285-295. [CrossRef]

41. Yoon, H.J.; Moon, M.E.; Park, H.S.; Im, S.Y.; Kim, Y.H. Chitosan oligosaccharide (COS) inhibits LPS-induced inflammatory effects in RAW 264.7 macrophage cells. Biochem. Biophys. Res. Commun. 2007, 358, 954-959. [CrossRef] [PubMed]

42. Li, Y.; Liu, H.T.; Xu, Q.S.; Du, Y.G.; Xu, J. Chitosan oligosaccharides block LPS-induced O-GlcNAcylation of NF-kappa B and endothelial inflammatory response. Carbohydr. Polym. 2014, 99, 568-578. [CrossRef] [PubMed]

43. Yousef, M.; Pichyangkura, R.; Soodvilai, S.; Chatsudthipong, V.; Muanprasat, C. Chitosan oligosaccharide as potential therapy of inflammatory bowel disease: Therapeutic efficacy and possible mechanisms of action. Pharmacol. Res. 2012, 66, 66-79. [CrossRef]

44. Lee, H.J.; Park, J.M.; Han, Y.M.; Gil, H.K.; Kim, J.; Chang, J.Y.; Jeong, M.; Go, E.J.; Hahm, K.B. The role of chronic inflammation in the development of gastrointestinal cancers: reviewing cancer prevention with natural anti-inflammatory intervention. Expert Rev. Gastroenterol. Hepatol. 2016, 10, 129-139. [CrossRef] [PubMed]

45. Zhou, Z.J.; Wang, L.; Feng, P.P.; Yin, L.H.; Wang, C.; Zhi, S.X.; Dong, J.Y.; Wang, J.Y.; Lin, Y.; Chen, D.P.; et al. Inhibition of epithelial TNF-alpha receptors by purified fruit bromelain ameliorates intestinal inflammation and barrier dysfunction in colitis. Front. Immunol. 2017, 8, 1468. [CrossRef] [PubMed]

46. Pangestuti, R.; Bak, S.S.; Kim, S.K. Attenuation of pro-inflammatory mediators in LPS-stimulated BV2 microglia by chitooligosaccharides via the MAPK signaling pathway. Int. J. Biol. Macromol. 2011, 49, 599-606. [CrossRef] [PubMed]

47. Sánchez, Á.; Mengíbar, M.; Fernández, M.; Alemany, S.; Heras, A.; Acosta, N. Influence of preparation methods of chitooligosaccharides on their physicochemical properties and their anti-inflammatory effects in mice and in RAW 264.7 macrophages. Mar. Drugs 2018, 16, 430. [CrossRef] [PubMed]

48. Lee, S.-H.; Senevirathne, M.; Ahn, C.-B.; Kim, S.-K.; Je, J.-Y. Factors affecting anti-inflammatory effect of chitooligosaccharides in lipopolysaccharides-induced RAW264.7 macrophage cells. Bioorg. Med. Chem. 2009, 19, 6655-6658.

49. Jeuniaux, C. Chitinases. Methods Enzymol. 1966, 8, 644-650.

(C) 2019 by the authors. Licensee MDPI, Basel, Switzerland. This article is an open access article distributed under the terms and conditions of the Creative Commons Attribution (CC BY) license (http://creativecommons.org/licenses/by/4.0/). 